\title{
Akateemisen työn merkityksellisyys ja yliopiston muuttuvat vaatimukset
}

\author{
Yliopistolle asetetut vaatimukset vahvistaa taloushyötyjä ja \\ kilpailukykyä ovat ristiriidassa yliopiston sivistystehtävän kanssa. \\ Sivistyseetokseen identifioituneet kasvatus- ja kielitieteilijät \\ kokevat oman työnsä arvostuksen heikentyneen ja sen myötä \\ työnsä merkityksellisyyden vähentyneen. Jos yliopisto ohjaa tutkija- \\ opettajiaan sitoutumaan pääosin oman uran edistämiseen julkaisemalla \\ ja hankkimalla rahoitusta, se ei välttämättä kykene tuottamaan \\ yhteiskunnallista hyötyä, laatua ja vaikuttavuutta.
}

y

JULKINEN VALTA ON 2000-LUVULLA alkanut vaatia yliopistoilta yhä enemmän taloudellisen hyödyn tuottamista ja kansallisen kilpailukyvyn vahvistamista. Suomessa tämä kehitys huipentui vuonna 2010 toteutettuun yliopistouudistukseen, jonka tavoitteena oli muun muassa lisätä tutkimuksen ja opetuksen laatua ja vaikuttavuutta sekä jakaa resursseja huipputason tutkimukseen (Opetus- ja kulttuuriministeriö 2017).

Taloudellisen kilpailun, suoritusten ja tehokkuuden mittaamisen ja yrityksille ominaisten toimintatapojen tuomisen yliopistoon on kuitenkin nähty sopivan huonosti yhteen yliopistojen sivistys- ja kasvatusajatteluun perustuvan tieteellisen toimin- nan kanssa (esim. Pasanen 2015; Hannukainen \& Brunila 2017). Yliopiston henkilöstö on suurelta osin suhtautunut yliopistossa toteutettuihin uudistuksiin varauksellisesti ja katsonut niiden vähentäneen heidän työssään kokemaa merkityksellisyyttä (Rinne ym. 2012).

Yliopiston arvojen muutosten myötä yliopiston työntekijöiden identiteettien on nähty muuttuneen (Henkel 2005; Komulainen ym. 2019). Modernia identiteettiä tarkastellut filosofi Charles Taylor (1989) tulkitsee identiteetin yksilön ymmärrykseksi siitä, mitkä asiat ovat hänelle erityisen tärkeitä. Yksilön identiteettiä määrittävät sitoutumiset ja identifikaatiot. Ne tarjoavat moraalisen kehyksen, jonka 


\section{HENKILÖSTÖ ON}

\section{SUHTAUTUNUT YLIOPISTOSSA}

\section{TOTEUTETTUIHIN UUDISTUKSIIN}

VARAUKSELLISESTI.

mukaan yksilö pystyy määrittelemään, mikä on hyvää ja arvokasta, miten hänen tulisi toimia ja mitä kannattaa tai vastustaa. (Taylor 1989, 27-28).

Moraalisen kehyksen ulottuvuuksia ovat muiden kunnioittaminen ja velvollisuudet muita kohtaan, muilta saatava arvostus sekä merkityksellisyyden toteutuminen omassa elämässä (Henkel 2005, 157; Taylor 1989, 15). Merkityksellisyyden kokemista omassa työssä voidaan siis pitää yliopistolaisten identiteettiä määrittävänä asiana. Se auttaa heitä orientoitumaan omassa työssään sekä valitsemaan asioita, joihin he sitoutuvat ja joita he pyrkivät työnsä kautta edistämään. Myös velvollisuudet muita, eli yliopistoyhteisöä ja laajemmin koko yhteiskuntaa, kohtaan sekä itseen kohdistuvan arvostuksen odotus ohjaavat yliopistolaisten valintoja ja sitoumuksia työssä.

'Työn merkityksellä' tarkoitetaan yksilön omaa tulkintaa siitä, millainen rooli ja merkitys hänen työllään on hänen oman elämänsä kontekstissa. Työ voi merkitä esimerkiksi toimeentulon hankkimista, kutsumusta, ajanvietettä tai sortoa ja alistamista (Pratt \& Ashforth 2003). Työlle annettujen merkitysten voidaan ajatella kertovan siitä, kuinka työhön identifioidutaan ja sitoudutaan, kuinka tärkeänä osana omaa identiteettiä sitä pidetään.

'Työn merkityksellisyydellä' puolestaan viitataan yksilön oman työn tavoitteiden ja päämäärien arvoon, jonka yksilö on arvioinut omien ihanteidensa ja standardiensa pohjalta (May, Gilson \& Harter 2004). Koska ihminen pyrkii jatkuvasti kokemaan merkityksellisyyttä työssään (Cohen-Meitar, Carmeli \& Waldman 2009), hän todennäköisesti rakentaa sitä tavoittelemiensa asioiden kautta. Työn merkityksellisyyden kokemusta voidaan siten pitää sekä työssä tavoiteltavana asiana että suunnannäyttäjänä, joka osana moraalista kehystä ohjaa työssä tehtäviä valintoja.
Identiteetin ja merkityksellisyyden rakentumisessa olennainen on yhteisö, johon yksilö kuuluu (Henkel 2005, 157; Taylor 1989, 36). Yksilö voi oman moraalisen kehyksensä ohjaamana identifioitua yhteisöön, sen arvoihin ja tavoitteisiin. Yliopistomaailmassa yksi merkittävä identiteettiä ja työn merkityksellisyyttä määrittävä yhteisö on tieteenala (Henkel 2005, 158).

Tieteenalojen on ajateltu muodostavan akateemisia heimoja, jotka eroavat toisistaan tavoitteiltaan, arvoiltaan, uskomuksiltaan ja toimintatavoiltaan (Becher 1989; Ylijoki 1998). Ne voidaan luokitella karkeasti niin sanottuihin koviin tieteisiin, joissa vallitsee paradigmaattinen yhtenäisyys ydinteorioista ja käsitteistä, sekä pehmeisiin tieteisiin, joissa tällaista yhtenäisyyttä ei ole (Becher 1989; Rinne ym. 2012, 65). Kovat tieteet usein mielletään yritysmäisemmin toimiviksi kuin pehmeät tieteet, ja niitä arvostetaan, sillä niiden odotetaan luovan kansallista kilpailukykyä (Kankaanpää 2013, 74).

Tieteenalojen on havaittu eroavan toisistaan muun muassa suhtautumisessa yliopistossa tapahtuviin muutoksiin. Yliopistotyön muutosta tutkineiden Risto Rinteen ja kollegoiden (2012) tutkimuksessa koviin tieteisiin lukeutuvaa lääketiedettä edustava yliopistohenkilöstö suhtautui uuteen yliopistopolitiikkaan, kuten tulosvastuuseen ja yritysmäistymiseen, muita tieteenaloja myönteisemmin. Sen sijaan kaikkein kielteisimmin uuden yliopistopolitiikan koki pehmeisiin tieteisiin luokiteltuja humanistisia tieteitä, muun muassa kielitieteitä, edustava yliopistohenkilöstö. Niin ikään pehmeitä tieteitä edustavat kasvatustieteilijät sijoittuivat suhtautumistavaltaan lääketieteen ja humanististen tieteiden väliin. (Rinne ym. 2012, 107-112.)

Olen valinnut tässä artikkelissa tarkasteltaviksi tieteenaloiksi juuri kasvatus-, lääke- ja kielitieteet, jotta tavoittaisin mahdollisimman laajan kirjon yliopistossa työskentelevien tutkijoiden ja opettajien tapoja suhtautua yliopistotyön muutokseen, identifioitua työhönsä ja rakentaa työnsä merkityksellisyyttä.

Akateemista työtä käsittelevässä tutkimuskirjallisuudessa ei tyypillisesti ole käytetty työn merkityksen ja merkityksellisyyden käsitteitä, vaan yliopistotyötä ja sen muutosta on jäsennetty muun muassa akateemisen identiteetin käsitteen avulla (esim. Clegg 2008; 


\section{SIVISTYSYLIOPISTOSSA}

\section{TAVOITELLAAN TOTUUTTA}

\section{SEN ITSENS $\ddot{A}$ VUOKSI.}

Hakala 2009; Ylijoki ja Ursin 2013; Komulainen ym. 2019). Yliopistohenkilöstön työlleen antamien merkitysten esiintuominen voi kuitenkin lisätä ymmärrystä yliopistolaisten identiteettien ja sitoumusten moninaisuudesta ja auttaa ennakoimaan niiden kehitystä. Työhön liittyvien identifikaatioiden tarkastelu suhteessa yliopistotyön muuttuviin vaatimuksiin yksilöiden tasolla tuo uutta näkökulmaa akateemisen työn tutkimukseen.

\section{SIVISTYSYLIOPISTON IHANTEISTA YRITYSMÄISEN YLIOPISTON VAATIMUKSIIN}

Yliopistosta ja akateemisesta työstä keskusteltaessa käytetään usein sivistysyliopiston käsitettä. Siihen liitetään yliopiston kulttuurinen ja sivistyksellinen tehtävä, kuten kansalaisten kasvattaminen, yhteiskunnan henkisen kehityksen edistäminen ja osaamisen kulttuurinen hyödyntäminen (Kankaanpää 2013, 131-132). Sivistysyliopistoajattelussa koulutuksen merkitys määrittyy kulttuurin kehityksestä ja yksilön kasvun ideaaleista (Tomperi 2009, 182).

Sivistysyliopistoihanteeseen sisältyy lisäksi ajatus, että yliopisto- tai tiedeyhteisö määrittelee, millaista on hyvä tiede. Akateemisen arvioinnin läpäissyttä tietoa on pidetty pätevänä ja tieteellisiin kriteereihin ja menetelmiin perustuvaa vertaisarviointia parhaana takeena tieteen edistymiselle (Miettinen ym. 2006, 33; Williams 2007). Sivistysyliopistoajattelu tulee esiin yliopiston hahmottamisessa ideana eli instituutiona, jossa tavoitellaan totuutta sen itsensä vuoksi. Totuutta tavoitellaan tutkimuksen avulla, ja sitä pyritään jakamaan muille julkaisuissa ja opetuksessa. (Himanka 2018, 181.) Yliopiston ideaa voi pitää yliopistolaisten yhtenä identifioitumisen kohteena, kollektiivisena käsityksenä siitä, millaiseen yliopistoon he haluavat sitoutua.

Yliopiston yhteiskunnallista roolista käytävässä keskustelussa puhutaan usein "humboldtilaisesta" sivistysyliopistosta. Historioitsija Mitchell Ash (2008, 41-46) kutsuu sivistysyliopiston periaatteiden liittämistä saksalaisen filosofin ja kielitieteilijän Wilhelm von Humboldtin (1767-1835) yliopistonäkemyksiin Humboldt-myytiksi. Sen mukaan yliopistojen tulisi olla korkeinta opetusta antavia laitoksia, joissa vallitsevat tutkimuksen ja opetuksen vapaus ja ykseys, ja joiden tulisi edistää ajattelua, itsensä kehittämistä ja sivistämistä. Ash näkee Humboldtin symboloivan autonomiaa ja yliopistolaisten valtaa päättää yliopistoa koskevista asioista sekä rakentaa yliopistolaisten yhteistä identiteettiä ja jaettuja merkityksiä.

Suomalainen sivistysyliopistokeskustelu on saanut vaikutteita paitsi Humboldtin myös filosofi Johan Vilhelm Snellmanin (1806-1881) ajatuksista. Snellman korosti Humboldtin tavoin opetuksen ja tutkimuksen välistä yhteyttä, mutta toisin kuin Humboldt, hän piti tärkeänä myös yliopiston ja yhteiskunnan välistä vuorovaikutusta. Snellmanin mukaan yliopiston tehtävänä oli kouluttaa yhteiskuntaan virkamiehet, vaikuttaa kirjoitusten kautta koko kansakunnan sivistykseen ja ottaa kantaa isänmaalle kulloinkin tärkeisiin kysymyksiin. (Miettinen 2018,9.)

Snellman painotti sitä, että yliopistossa opiskelija kasvaa yhtäältä itsenäiseksi ajattelijaksi ja toisaalta hyväksi kansalaiseksi. Yliopisto toteutti vapaata tutkimusta, ja samalla sieltä valmistuvien tuli pystyä kehittämään valtiota. (Himanka 2018, 41.) Vielä 1960-luvulla sivistyneistön tehtävänä pidettiin myös kansan johtamista ja kansallista eheyttämistä (Kolbe 1996, 17-23).

Suomalaista tiede- ja korkeakoulupolitikkaa tarkastelleiden Panu Raatikaisen ja Heikki Tunkkarin (1991) mukaan yliopiston rooli ja merkitys yhteiskunnassa alkoivat muuttua 1980-luvulla markkinoiden globalisaation myötä. Tiedosta tuli informaatioyhteiskunnassa tärkeä tuotannontekijä, jolloin varsinkin tuotekehittelyä palvelevan tutkimuksen merkitys korostui (Raatikainen \& Tunkkari 1991, 11-15). Taloushyötyä tavoitteleva elinkeinoelämä korosti ammattilaisuutta, täsmätutkintoja ja nopeaa valmistumista sekä odotti yliopistoilta innovaatioita ja nopeasti sovellettavia tieteellisiä tuloksia (Björn, Saarti \& Pöllänen 2017). Kyetäkseen vastaamaan yhteiskunnalliseen palvelutehtäväänsä yliopistot uudistivat 
YLIOPISTOJEN TEHTÄVÄKSI

MIELLETÄ̈̈N YHTEISKUNTAA

HYÖDYTT ̈̈VIEN PALVELUJEN,

TIEDON JA TYÖVOIMAN

TUOTTAMINEN.

johtamisjärjestelmiään yritysmaailman oppien mukaan ja loivat suorituskykyä mittaavia järjestelmiä, jotka asettivat uusia vaatimuksia tutkijoille ja opettajille (Kallio ym. 2016, 689).

Yliopiston uutta olemusta ja ihannetta on luonnehdittu muun muassa yritysmäisen yliopiston käsitteellä, jota kasvatustieteilijä Jenni Kankaanpää (2013, 62) on käyttänyt kuvaamaan yliopiston ja sen toimintaedellytysten muutosta erityisesti 2000-luvulla. Se tarkoittaa yritysmäisten toimintatapojen tuomista yliopistoon ja yritysmaailmalle tyypillisten tehokkuus-, hyöty- ja tuottavuusodotusten kohdistamista yliopistoihin. Käytän yritysmäisen yliopiston käsitettä samassa merkityksessä.

Ulkoapäin tuodut, taloushyötyyn tähtäävät odotukset kyseenalaistivat sivistysyliopistoajattelun mukaista yliopiston ideaa. Tieteen legitimaatio totuuden etsintänä ja viisauden edistämisenä joutui väistymään, kun tieteen tekemisen tuloksellisuus ja talousvaikutukset muuttuivat ensisijaisiksi yhteiskunnallisen merkityksellisyyden mittareiksi (Koski 2002, 35). Filosofi Juha Himangan $(2018,45)$ mukaan yliopiston yhtenäisen perusajatuksen väistyessä yliopistoa aletaan tarkastella sen tehtävien kautta. Tällöin pohditaan, miten yliopisto voi auttaa opiskelijoiden ja yhteiskunnan tavoitteiden saavuttamisessa, esimerkiksi edistämällä talouskasvua tuottamalla innovaatiota ja opiskelijoiden henkilökohtaista uramenestystä.

Korkeakoulupolitiikkaa tutkineen Jarkko Tirrosen (2005) mukaan yliopiston yhteiskunnallisen merkityksen muutos on vaatinut akateemisten perusarvojen uudelleenarvioimista. Arvolähtökohdat pohjautuvat yhä enemmän yhteiskunnan ja työmarkkinoiden tavoitteisiin, ja talousperusteinen ajattelutapa on tullut osaksi yliopistojen toimintaa. Yliopis- tojen tehtäväksi on mielletty yhä enemmän yhteiskuntaa hyödyttävien palvelujen, tiedon ja työvoiman tuottaminen, jolloin yliopistokoulutuksen työelämäsidonnaisuus on vahvistunut. (Tirronen 2005, 110, 115). Yliopistotutkimuksessakin yhteiskunnallisen hyödyn on nähty nousseen tärkeäksi tavoitteeksi. Yhteiskuntatieteilijä Johanna Hakala $(2009,180)$ on havainnut tutkimuksen tuottaman hyödyn merkittäväksi nuoria tutkijoita motivoivaksi tekijäksi: tutkimuksen lähtökohtana tulee olla todellisen elämän ongelma ja ilmiö tieteenalan teorioista ja perinteistä nousevan tutkimusaiheen sijaan.

Vaikka yliopiston toimintaympäristö on muuttunut siinä missä yliopistolle asetetut odotuksetkin, sivistysyliopiston ihanteita on voitu havaita vielä 2000-luvun yliopistossakin. Ne ilmenevät muun muassa yliopistotyön mielekkyydestä kertovassa narratiivissa, jota yhteiskuntatieteilijä Oili-Helena Ylijoki (2009) kutsuu yliopiston lumotarinaksi. Siinä korostuvat perinteiset akateemiset ideaalit, kuten vapaus ja autonomia, sekä opetuksen ja tutkimuksen välinen yhteys. Lumotarina perustuu tutkijan syvään henkilökohtaiseen tutkimustyöhön kohdistuvaan kiinnostukseen, jonka hän kokee kutsumuksena ja elämäntehtävänä, jossa hän tuntee olevansa oma itsensä ja johon hän sitoutuu kokonaisvaltaisesti. (Ylijoki 2009, 86-89.) Tieteen onkin katsottu vaativan tiedeyhteisön edustajilta ehdotonta omistautumista, sitä on pidetty edellytyksenä omalle edistykselle ja totuuden löytämiselle: perhe, ystävät ja vapaa-aika ovat joutuneet väistymään tieteen vaatimien uhrausten tieltä (Koski 2002, 41).

Hakalan $(2009,178)$ mukaan yliopiston muuttuneiden olojen, kuten ulkoisen rahoituksen lisääntymisen, työkuorman kasvamisen ja epävarmojen uranäkymien, myötä perinteinen tapa ymmärtää akateemista työtä ei enää tarjoa sanastoa, jonka avulla yliopistolaiset voisivat jäsentää kokemuksiaan. Sosiologi Burton R. Clark $(1997,36)$ on ollut huolissaan akateemisen työn muuttumisesta "vain työksi", jossa työstä itsestään saatava sisäinen tyydytys vähenee ja välineelliset palkkiot muuttuvat tärkeämmiksi. Yliopistotyötä tutkineet Kayleigh Rosewell ja Paul Ashwin $(2019,7)$ havaitsivat tällaista orientaatiota tutkiessaan akateemiselle työlle annettuja merkityksiä. 


\section{OPETUKSEN JA TUTKIMUKSEN \\ PAINOARVO VAIHTELEVAT \\ TEHT ÄVÄNIMIKKEEN JA \\ TYÖSUHTEEN LAADUN MUKAAN.}

Vaikka kaikki heidän haastattelemansa tutkijat ja opettajat pitivät työtään yliopistossa tärkeänä, erityisesti miespuoliset haastateltavat kertoivat työnsä olevan heille "vain työtä", joka tarjoaa palkkaa ja tunnustusta (Rosewell \& Ashwin 2019, 7).

Yhteiskunnan yliopistolle asettamissa odotuksissa painottuvat siten yhä enemmän yliopiston tuottama rahassa mitattava hyöty ja määrälliset suoritteet. Sivistysyliopiston aineettomat ihanteet voivat kuitenkin tarjota tutkijoille ja opettajille aineksia työnsä merkityksellisyyden rakentamiselle, joten he voivat pyrkiä pitämään niitä yllä myös yritysmäisen yliopiston puitteissa.

\section{AINEISTO JA MENETELMÄT}

Kysyn tässä artikkelissa,

1) millaisia merkityksiä kasvatus-, lääke- ja kielitieteitä edustavat tutkija-opettajat antavat työlleen, 2) mihin asioihin he työssään identifioituvat ja miten he rakentavat näistä asioista työnsä merkityksellisyyttä sekä

3) miten he sovittavat yhteen omia identifikaatioitaan ja yliopistotyölle asetettuja vaatimuksia.

Aineisto koottiin siten, että yliopistossa työskenteleviä tutkija-opettajia pyydettiin kirjoittamaan kuvauksia heidän suhtautumisestaan omaan työhönsä. Kirjoitustehtävä toteutettiin verkossa sähköisellä lomakkeella. Keräsin aineiston osana väitöstutkimustani, joka tarkastelee työn merkityksellisyyden rakentumista yliopistouudistusten ja muuttuvien yliopistotyön vaatimusten kontekstissa. Tämä artikkeli koskee väitöstutkimuksen yhtä osatutkimusta, joten hyödynnän vain osaa kerätystä aineistosta.

'Tutkija-opettajilla' tarkoitan henkilöitä, joiden pääasiallinen työtehtävä yliopistossa on tutkimus ja opetus tai jompikumpi. Luen tähän ryhmään seuraavat yliopistossa käytössä olevat tehtävänimikkeet: apulaisprofessori, professori, projektitutkija, tutkijatohtori, tutkija, yliopistonlehtori, yliopisto-opettaja ja yliopistotutkija. Nimikkeet esiintyivät lähes kaikissa kohteeksi valituissa tieteenalayksiköissä, ja ne edustavat suurinta osaa yliopistojen tutkimus- ja opetushenkilöstöstä. Tutkittava joukko ei kuitenkaan ole yhtenäinen: opetuksen ja tutkimuksen painoarvo sekä valta ja mahdollisuudet vaikuttaa omaan työhön ja työyhteisöön vaihtelevat tehtävänimikkeen ja työsuhteen laadun mukaan.

Lokakuussa 2017 lähetin lomakkeen vastattavaksi kahteen suurehkoon suomalaiseen yliopistoon, joita kutsun nimillä yliopisto A ja yliopisto B. Kohdistin sen kasvatustieteiden, lääketieteen ja kielitieteiden tiedekunnassa työskenteleville tutkija-opettajille. Yliopisto A:ssa mukaan otettiin lisäksi biotieteitä edustavat tutkija-opettajat, sillä he kuuluivat samaan tiedekuntaan lääketieteen kanssa, ja biotieteet luonnontieteinä lukeutuvat lääketieteen tavoin niin sanottuihin koviin tieteisiin. Kasvatustieteissä vastaajajoukkoon kuului sekä opettajankoulutusta edustavia että generalisteiksi luonnehdittavia tutkija-opettajia.

Lomakkeen sai vastattavakseen 610 tutkija-opettajaa, noin 300 molemmista yliopistoista. Kullekin kuudelle kohteena olleelle tieteenalayksikölle laadittiin oma erillinen lomakkeensa, jotta niitä edustavat vastaukset pysyisivät teknisesti erillään toisistaan. Vastaajilta kysyttiin taustatietoina ikäryhmää, sukupuolta ja ensimmäisen työsuhteen aloitusvuotta jossain suomalaisessa yliopistossa. Muita taustatietoja ei anonymiteetin säilymisen turvaamiseksi kysytty. Vastauksista oli pääsääntöisesti luettavissa, painottuivatko vastaajan työtehtävissä sekä opetus että tutkimus vai ainoastaan toinen niistä.

Vastauksia saatiin 117, joten koko aineiston vastausprosentiksi muodostui noin 19 prosenttia. Vastaajista 34 prosenttia edusti kasvatustieteitä, 48 prosenttia lääke- ja biotieteitä ja 18 prosenttia kielitieteitä. Vastaajien enemmistö, 62 prosenttia, oli naisia, ja suurin ikäryhmä olivat 40-55-vuotiaat, joita oli 44 prosenttia vastaajista. Vastaajat jakautuivat eri tavoin tieteenalayksikön, sukupuolen, ikäryhmän ja työn painotusten mukaan (taulukko $\mathbf{1}$ ). 


\begin{tabular}{|c|c|c|c|c|c|c|c|}
\hline & \multicolumn{3}{|c|}{ Yliopisto A $(\mathrm{N}=298)$} & \multicolumn{3}{|c|}{ Yliopisto B $(\mathrm{N}=312)$} & \multirow[b]{2}{*}{ Yhteensä } \\
\hline & $\begin{array}{l}\text { Kasvatus- } \\
\text { tieteet }\end{array}$ & Lääketiede* & $\begin{array}{l}\text { Kieli- } \\
\text { tieteet }\end{array}$ & $\begin{array}{l}\text { Kasvatus- } \\
\text { tieteet }\end{array}$ & Lääketiede & $\begin{array}{l}\text { Kieli- } \\
\text { tieteet }\end{array}$ & \\
\hline Vastaajien Ikm & 22 & 27 & 13 & 18 & 29 & 8 & 117 \\
\hline Vastausprosentti \% & 32 & 15 & 30 & 17 & 18 & 18 & 19 \\
\hline \multicolumn{8}{|l|}{ Sukupuoli } \\
\hline Naisia & 12 & 19 & 11 & 11 & 14 & 6 & 73 \\
\hline Miehiä & 9 & 8 & 1 & 7 & 13 & 2 & 40 \\
\hline Ei ilmoitettu & 1 & 0 & 1 & 0 & 2 & 0 & 4 \\
\hline \multicolumn{8}{|l|}{ Ikä } \\
\hline Alle 40-vuotiaat & 6 & 11 & 0 & 4 & 4 & 2 & 27 \\
\hline 40-55-vuotiaat & 8 & 9 & 10 & 4 & 15 & 5 & 51 \\
\hline Yli 55-vuotiaat & 7 & 7 & 3 & 10 & 9 & 1 & 37 \\
\hline Ei ilmoitettu & 1 & 0 & 0 & 0 & 1 & 0 & 2 \\
\hline \multicolumn{8}{|l|}{ Työtehtävät } \\
\hline Opetus ja tutkimus & 12 & 11 & 10 & 12 & 18 & 8 & 71 \\
\hline Opetus & 2 & 2 & 1 & 2 & 3 & 0 & 10 \\
\hline Tutkimus & 6 & 12 & 2 & 3 & 7 & 0 & 30 \\
\hline Ei ilmoitettu & 2 & 2 & 0 & 1 & 1 & 0 & 6 \\
\hline
\end{tabular}

*Vastaajissa oli myös tutkija-opettajia biotieteistä.

Taulukko 1. Vastaajien jakautuminen tieteenalayksiköittäin taustatietojen mukaan.

Aineistonkeruumenetelmääni voi kutsua teemakirjoittamiseksi. Tutkittavat kertovat siinä tiettyyn teemaan liittyvistä kokemuksistaan kuten teemahaastattelussa, mutta ilmaisevat itseään puhumisen sijaan kirjoittamalla (Apo 1995, 173-174; Laajalahti 2015). Teemakirjoittamisen metodologisena etuna on, että se tuo esiin tutkittavien jäsennykset siten, että tutkija on vaikuttanut niihin mahdollisimman vähän (Apo 1995, 176). Siksi oletin, että työlle annetut merkitykset ja työssä tavoiteltavat asiat tulisivat tutkija-opettajien teksteissä esiin mahdollisimman autenttisina ja moninaisina. Lisäksi menetelmä mahdollisti aineiston keräämisen laajemmalta kohdejoukolta kuin esimerkiksi haastattelututkimuksessa on mahdollista, mikä edisti aineiston moninaisuutta. Oletukseni oli, että omista kokemuksista kirjoittaminen itsenäisesti soveltuisi tutkimuksen kohderyhmälle, koska kirjoittaminen on olennainen osa tutkijan työtä.
Vastaajia pyydettiin kuvailemaan suhtautumistaan omaan työhönsä yliopistossa ja nykyistä yliopistoaan tai tieteenalayksikköään työskentely-ympäristönä tai työpaikkana. Kirjoittamista ohjasivat seitsemän avokysymystä, joista tämän artikkelin kannalta olennaisimpia ovat "Millaisia asioita tavoittelet tai haluat edistää työssäsi, ja miksi?", "Mitä työsi merkitsee sinulle?" ja "Ovatko työssä tavoittelemasi asiat tai työsi merkitys muuttuneet yliopistourasi aikana ja jos ovat, niin miten ja miksi?"

Aineistoa kertyi noin 140 sivua. Kuvausten pituus vaihteli vajaasta sivusta kolmeen sivuun. Niukimmissa kuvauksissa kysymyksiin oli vastattu vain yhdellä sanalla tai lauseella, ja joihinkin kysymyksiin oli saatettu jättää kokonaan vastaamatta. Runsaimmissa kuvauksissa omaa työtä yliopistossa ja sitä koskevaa problematiikkaa oli kuvattu monitahoisesti ja reflektoitu syvälläkin tasolla. Suurin osa kuvauksista sisälsi 
ANALYYSISSA HAIN

TUTKIJA-OPETTAJIEN JAKAMIA

TAVOITTEITA, MERKITYKSI $\ddot{A}$

JA YLIOPISTOTYÖLLE

ASETTAMIA IHANTEITA.

omakohtaista pohdintaa omasta työstä, joten aineisto oli analyysin kannalta hedelmällinen.

Koska kuvaukset olivat kerrontaan perustuvaa aineistoa, sovellan tutkimuksessa narratiivista lähestymistapaa. Sen mukaan ihmiset rakentavat identiteettiään ja maailmaa koskevaa tietoaan narratiivisesti; kertomusten avulla pyritään tuomaan esiin ihmisten oma tapa antaa asioille merkityksiä (Heikkinen 2001, 116-118; Hänninen 1999, 15, 34.).

Yksilöiden ajatellaan puhuvan kokemuksistaan käyttämällä sanoja, käsitteitä ja puheen muotoja, jotka tarjoutuvat heille heidän narratiivisessa ympäristössään (Gubrium \& Holstein 2008). Näitä diskursiivisia elementtejä aineistoni tutkija-opettajien voidaan nähdä käyttävän omasta työstään puhuessaan. Heidän kirjoittamansa kuvaukset on mahdollista käsittää puheeksi, jonka avulla he eivät pelkästään kuvaa näkemyksiään ja suhtautumistaan työhönsä vaan myös rakentavat suhdettaan työhön, identiteettiään sekä työnsä merkityksiä ja merkityksellisyyttä.

Analysoin aineiston laadullisen analyysin keinoin teemoittelemalla, mikä mahdollisti tutkimuskysymysten kannalta olennaisten asioiden poimimisen aineistosta ja niiden erottelun toisistaan (Eskola \& Suoranta 2014, 176). Analyysissa pyrin löytämään tutkija-opettajien kesken jaettuja tavoitteita, merkityksiä ja yliopistotyölle asetettuja ihanteita. Huomio kiinnittyi erityisesti tieteenalojen välisiin yhtäläisyyksiin ja eroihin. Samalla yritin päästä yhä syvemmälle prosessiin, jossa tutkija-opettajat moraalisen kehyksensä ohjaamina tasapainottelevat omien identifikaatioidensa ja ulkopuolelta asetettujen velvoitteiden välillä.

Analyysissa jaottelin ensin kunkin vastaajan kirjoittaman kuvauksen alustaviin teemaluokkiin sen perusteella, mitä työlleen antamiaan tavoitteita ja merkityksiä vastaaja toi siinä esiin. Sen jälkeen yhdistin temaattisesti toisiaan lähellä olevat luokat ja niiden sisältämät kuvausten osat eli otteet viideksi ylemmän tason teemaluokaksi, jotka ovat

1) tieteen ja tutkimuksen edistäminen

2) kasvattaminen, opettaminen ja sivistäminen

3) yhteiskunnallinen vaikuttaminen yleisesti

4) yliopistoyhteisön hyväksi työskenteleminen

5) yliopistotyön merkitykset tutkija-opettajille itselleen.

Analyysissä rakentuneita teemaluokkia voidaan pitää tahoina, joita varten yliopistotyötä tehdään, esimerkiksi tiede, opiskelijat, yhteiskunta ja yliopistoyhteisö, sekä tapoina rakentaa työn merkityksellisyyttä.

\section{TIETEEN EDISTÄMINEN ITSEISARVONA JA YHTEISKUNNALLISEN HYÖDYN TUOJANA}

Tutkijat tieteenalaan katsomatta pitivät tieteen ja tutkimuksen edistämistä yliopistotyön perusolemukseen kuuluvana tehtävänä, jota ei välttämättä tarvinnut perustella lainkaan. Vastaajat yli tieteenalarajojen identifioituvat laadukkaaseen ja hyvään tutkimukseen sekä uuden tiedon tuottamiseen. Tieteellistä laatua pidettiin arvona ja päämääränä, jota ei saanut alistaa muille tavoitteille.

Tieteenalat kuitenkin erottuivat toisistaan sen perusteella, millaiseksi tieteellinen toiminta miellettiin. Kasvatustieteissä korostettiin tutkimuksen sosiaalista ulottuvuutta, tietoa haluttiin välittää opiskelijoille ja viedä yliopiston ulkopuolelle. Lääke- ja biotieteilijät puhuivat tieteen ja tutkimustulosten viemisestä "eteenpäin", he käyttivät enemmän tiede-sanaa, kun muilla tieteenaloilla puhuttiin pääosin tutkimuksesta. Yksi vastaaja perusteli sitoutumistaan tieteelliseen laatuun seuraavasti:

"Myös henkilökohtaisen uran edistämisessä uskon, että korkealaatuiset, perustellut kokeet ja toistettavat [= "oikeat"] tulokset ovat pidemmällä tähtäimellä hyödyllisempiä kuin nopeasti tuotettu ja julkaistu 'sekundadata'." (yliopisto A, lääketiede tai biotieteet, nro 27, nainen, alle 40 vuotta) 


\section{KasVAtUStieteiss $\ddot{A}$}

\section{KOROSTETTIIN TUTKIMUKSEN}

\section{SOSIAALISTA ULOTTUVUUTTA.}

Edellisessä otteessa tulee esiin sivistysyliopistoihanteen mukainen ajatus tieteellisen laadun määrittelystä tiedeyhteisön asettamien kriteerien mukaisesti. Samalla siitä kuultaa kritiikki yritysmäisen yliopiston tuottavuustavoitteita kohtaan: Vastaaja näki nopeita tuloksia tuottavan tutkimuksen tieteellisesti heikompilaatuisena. Hän ei halunnut sitoutua siihen, vaikka edusti lääke- ja biotieteitä, joissa yritysmäisen yliopiston tavoitteita ei tyypillisesti problematisoida yhtä paljon kuin muilla tieteenaloilla (ks. Rinne ym. 2012).

Toinen lääke- ja biotieteitä edustava vastaaja taas yhdisti laadun ongelmattomasti yritysmäiselle yliopistolle ominaisiin tavoitteisiin, kuten globaaliin kilpailukykyyn:

"Tutkijana haluan edistää alani tiedettä kansainvälisellä huipputasolla. = Laadukasta, rehellistä, ajantasaista tutkimusta." (yliopisto A, lääketiede tai biotieteet, nro 6, nainen, alle 40 vuotta)

Monet vastaajat toivat esiin identifioitumistaan oman tieteenalansa tutkimukseen. Lääke- ja biotieteilijät kertoivat haluavansa edistää tutkimuksellaan esimerkiksi "oman erikoisalan lääketieteellistä tutkimusta" ja löytää "uusia merkittäviä biologisia ja biokemiallisia ominaisuuksia ja lainalaisuuksia”. Kasvatus- ja kielitieteilijät puolestaan halusivat tutkimuksella edistää ja kehittää omaa tieteenalaansa yleisemmin muun muassa lisätäkseen oman tieteenalansa arvostusta yritysmäisessä yliopistossa, jossa sen katsottiin jäävän alakynteen:

"[Haluan edistää] Tutkimuksessa henkisen ihmiskuvan merkitystä esim. biomedikaalisen ihmiskuvan rinnalla. Siksi koska nämä asiat ja humanistinen tutkimus ylipääään jäävät täysin jalkoihin nykyisessä yliopistossa, joka mittaa kaikkea numeraalisilla tuloksilla ja viime kädessä rahassa.” (yliopisto B, kielitieteet, nro 16, nainen, yli 55 vuotta)
Erityisesti yliopisto A:n kielitieteitä edustavat vastaajat toivat esiin tutkimuksen henkilökohtaista ulottuvuutta - omaehtoisuutta ja mielenkiintoisuutta. Kasvatustieteissä korostui tutkimuksen yleinen yhteiskunnallinen merkittävyys, kun taas lääketieteilijät halusivat tutkimuksella kehittää sairauksien hoitoa ja terveydenhuollon palveluita. Kiinnostusta tutkittaviin asioihin ja niiden yhteiskunnallista merkittävyyttä pidettiin usein samansuuntaisina tavoitteina:

"[Haluan] tutkia mielenkiintoisia ja yhteiskunnalle hyödyllisiä aiheita ja viedä tietoa myös yliopiston ulkopuolelle - tämä on minusta motivoivaa ja se on myös palkkatyöni." (yliopisto A, kasvatustieteet, nro 7, nainen, 40-55 vuotta)

Yllä oleva vastaaja näkee, että sekä itselle mielenkiintoiset että yhteiskunnallisesti hyödylliset tutkimusaiheet mahdollistavat sisäisen motivaation ja ulkoapäin tuotujen velvoitteiden välisen tasapainon. Myös Hakala (2009, 180-181) havaitsi, että tutkijoiden usko omien tulosten hyödynnettävyyteen voi vahvistaa heidän omia tutkimusintressejään ja lisätä oman työn merkityksellisyyden kokemusta.

\section{YLIOPISTO-OPETUS SIVISTÄMISENÄ JA AMMATTIIN VALMISTAMISENA}

Tutkija-opettajat eri tieteenaloilla mainitsivat opiskelijat merkittävänä tahona, jonka vuoksi he tekivät työtä yliopistossa. Yhteensä 55 vastaajaa, eli lähes puolet kaikista vastaajista, toi esiin työssä tavoittelemanaan asiana opiskelijat, heidän opettamisensa, kasvattamisensa tai sivistämisensä. Erityisen vahvaa opiskelijoihin sitoutuminen oli kielitieteissä: jopa 16 vastaajaa eli 76 prosenttia tieteenalaa edustavista vastaajista toi esiin opiskelijoiden tärkeyden omassa työssään. Kasvatustieteissä vastaava osuus oli 50 prosenttia ja läk̈ke- ja biotieteissä 34 prosenttia. Vähäisempi opiskelijoiden korostaminen lääke- ja biotieteissä selittyy osittain sillä, että näillä tieteenaloilla oli eniten vastaajia, joiden työtehtävät painottuivat pelkästään tutkimukseen.

Koska lääke- ja biotieteissä pääosa opiskelijoista valmistuu ammattiin, jossa vaaditaan tarkoin määriteltyjen asioiden hallintaa, näitä tieteenaloja edustavat 
SUURI OSA TUTKIJA-

OPETTAJISTA RAKENSI

TYÖNSÄ MERKITYKSELLISYYTTÄ

\section{YHTEISKUNNALLISEN}

VAIKUTTAVUUDEN POHJALTA.

vastaajat korostivat osaavien ammattilaisten ja ammattilaissukupolvien koulutusta. He painottivat oman alan asiantuntemusta, kuten tauteihin, anatomiaan ja vanhusten hoitoon liittyvien asioiden hallintaa. Kielitieteissäkin puhuttiin opiskelijoiden kasvattamisesta "täysivaltaisiksi kollegoiksi" ja "kielentutkijoiksi" sekä ammattitaitoisten alansa asiantuntijoiden kehittymisen tukemisesta.

Vaikka kasvatustieteissäkin koulutetaan opiskelijoita muun muassa opettajan ammattiin, kasvatustieteiden edustajat eivät kuitenkaan puhuneet ammattilaisten kouluttamisesta työelämää varten. Sen sijaan he pyrkivät ohjaamaan opiskelijoiden kasvua oikeaan suuntaan, jotta heistä tulisi "laajasti sivistyneitä, itsenäisesti ajattelevia" sekä "kriittisiä, viisaita, maailman epäoikeudenmukaisuuksia ja julmuuksia vastaan toimivia asiantuntijoita”. Kasvatustieteilijät puhuivat ammattilaisuuden sijaan sivistyksen, asiantuntemuksen ja osaamisen kehittämisestä. He identifioituvat siis enemmän yleisempään sivistykseen kuin ammattilaisuuteen.

Sivistystä pidettiin varsinkin kasvatustieteissä vastavoimana yritysmäiselle yliopistolle ominaisille tehokkuustavoitteille, suoritusten mittaamiselle ja kontrollille. Markkinaeetoksen katsottiin heikentävän mahdollisuuksia rakentaa oman työn merkityksellisyyttä panostamalla opiskelijoihin ja laadukkaaseen opetukseen:

"Vastoin markkinayliopiston eetosta, tavoittelen hyvää opetusta ja hyvää suhdetta opiskelijoihin." (yliopisto A, kasvatustieteet, nro 6, mies, 40-55 vuotta)
Lääketieteissä koettiin keskimäärin vähemmän omien ja yritysmäisen yliopiston tavoitteiden välistä ristiriitaa verrattuna kasvatus- ja kielitieteisiin. Yksi lääketiedettä edustava tutkija-opettaja kuitenkin katsoi tehokkuustavoitteiden heikentävän mahdollisuuksia kasvattaa opiskelijoita kriittisiksi, itsenäisiksi ajattelijoiksi, jotka pärjäisivät työelämässä:

"Sivistysyliopiston pitkä ja perusteellinen koulutus on muuttunut fakki-idiootteja suoltaviksi tutkintoputkiksi, joiden tuottamat broilerit ovat täysin työnantajiensa ohjailtavissa." (yliopisto B, lääketiede, nro 8, mies, yli 55 vuotta)

Puhuessaan suhteesta opiskelijoihin vastaajat käyttivät kuitenkin aineksia myös yritysmäiselle yliopistolle ominaisesta puhetavasta. Lääke- ja biotieteilijät kertoivat haluavansa edistää muun muassa "valtakunnan parasta opetustoimintaa" ja "ydinaineksen osaamisen tavoittelua". Näitä ilmaisuja voidaan pitää yhteensopivina koville tieteille tyypillisten kilpailullisuuden ideaalien kanssa (Becher 1994), jotka ovat sopusoinnussa yliopiston yritysmäistymisen kanssa. Yksi kielitieteitä edustava vastaaja kuvasi suhdettaan opiskelijoihin seuraavasti:

”Näen työni asiakaspalveluna, ja 'asiakkaitani' ovat opiskelijat. Koen tekeväni työtäni heitä varten, ja palkitsevinta on nähdä heidän edistyksensä." (yliopisto A, kielitieteet, nro 1, nainen, 40-55 vuotta)

Yllä oleva vastaaja rakentaa työnsä merkityksellisyyttä opiskelijasuhteen kautta puhumalla opiskelijoista asiakkaina ja kasvatuksesta heille tuotettavana palveluna. Tämä ei vastannut kielitieteilijöiden yleistä puhetapaa, mikä voi kertoa siitä, että yritysmäinen sanasto voi levitä niillekin tieteenaloille, joille se on vähemmän luonteenomainen.

Varsinkin kasvatustieteitä edustavat tutkija-opettajat näyttivät identifioituneen jo Snellmanin esiin tuomaan tavoitteeseen kasvattaa opiskelijoita palvelemaan ja kehittämään yhteiskuntaa (Himanka 2018). Kasvatustieteilijät sitoutuivat kasvattamaan "osaavia asiantuntijoita yhteiskunnan palvelukseen" ja "yhteiskunnallisia vaikuttajia", ja luomaan heille mahdollisuuksia työskennellä "tasa-arvon ihanteiden" ja "sosiaalisen oikeudenmukaisuuden" eteen. 
Opetuksen ja kasvatuksen yhteiskunnallisuutta korostettiin kielitieteissäkin:

"Intohimoni on tehdä perusasiat mahdollisimman hyvin. Yliopiston perustehtäviä ovat tutkimus ja opetus. Kaikki opetus on tärkeää, mutta yhteiskunnallisesti erityisen merkittävää on uusien opettajien kouluttaminen lukioihin ja perusopetukseen. Arvostan paljon oman pääaineeni (suomen kieli) perus- ja aineenopintoja, ja opetan mielelläni niihin liittyviä kursseja." (yliopisto B, kielitieteet, nro 7, nainen, 40-55 vuotta)

Yllä olevassa otteessa vastaaja rakentaa työnsä merkityksellisyyttä erityisesti yliopiston perustehtäviin kuuluvan opetuksen pohjalta. Hänen voi nähdä rakentavan puheessaan samalla työnsä yhteiskunnallista merkitystä.

\section{YHTEISKUNNALLINEN VAIKUTTAMINEN KANSAKUNNAN PALVELEMISENA JA OHJAAMISENA}

Suuri osa eri tieteenaloja edustavista tutkija-opettajista rakensi työnsä merkityksellisyyttä yhteiskunnallisen vaikuttavuuden pohjalta. Kaikilla kolmella tieteenalalla puhuttiin "maailmanparantamisesta", joka näyttäytyi tieteenalarajat ylittävänä tutkija-opettajien identifikaation kohteena. Tiedettä pidettiin yhteiskunnallisen vaikuttamisen välineenä, jonka avulla voidaan saada aikaan positiivista muutosta maailmassa. Vaikka vastaajat toivat yhteiskunnallisen vaikuttavuuden esiin myös tutkimuksen ja opetuksen yhteydessä, he puhuivat siitä yliopistotyöhön yleisestikin liittyvänä asiana.

Kasvatus- ja kielitieteilijät halusivat vaalia työssään yhteiskunnallisia, aineettomia arvoja, kuten "sivistystä", "ekologisuutta", "demokratiaa" ja "ihmisoikeuksia”, sekä edistää näiden toteutumista yhteiskunnassa. Perusteluna todettiin muun muassa, että se on "etuoikeutetun, korkean koulutuksen saaneen suoranainen velvollisuus". Yhteiskunnallisten arvojen edistämisen voi ajatella ilmentävän sivistysyliopistoihanteen mukaista yliopiston roolia kansakunnan ja sen henkisen kehityksen ohjaajana (Kolbe 1996). Aineettomien arvojen tavoittelua ja sivistyksellisen perustan tärkeyttä tuotiin esiin muun muassa seuraavasti:

"Nykyään puhutaan paljon kaikenlaisista kärkihankkeista, lippulaivoista ja muusta sellaisesta. Mitään kärkihankkeita ei kuitenkaan synny, jos perusta ei ole kunnossa. Toimin opettajana ja tutkijana humanistisella alalla (kielitiede). Humanistisille tieteenaloille on tyypillistä, että niiden tuloksia on vaikea suoraan tuotteistaa. Edistämme sellaisia aineettomampia arvoja kuin viestintä, sivistys tai yhteisöllisyys. Erityisesti ns. yleissivistyksen merkitystä ei mielestäni tiedosteta eikä arvosteta tarpeeksi." (yliopisto B, kielitieteet, nro 15, nainen, $40-55$ vuotta)

Yllä olevassa otteessa ilmenee sivistysyliopistoihanteen mukaisen yleissivistyksen ja yritysmäisen yliopiston korostaman tuottavuuden välinen jännite Vastaaja identifioituu sivistysyliopiston aineettomiin arvoihin, joiden hän ei näe yritysmäisessä yliopistossa saavan riittävästi tunnustusta. Hän ei kuitenkaan pidä sivistystä ja yliopiston tuottamaa hyötyä pelkästään toisilleen vastakkaisina tavoitteina, vaan pitää sivistystä välttämättömänä myös yritysmäiseltä yliopistolta odotettavien innovaatioiden luomisessa.

Lääke- ja biotieteilijät rakensivat työnsä merkityksellisyyttä yleisemmän ihmiskunnan hyvän lisäksi konkreettisten terveyspalvelujen kehittämisen pohjalta. He kertoivat työskentelevänsä muun muassa edistääkseen "palvelujen toimivuutta ja laatua", "löytääkseen uusia hoitokeinoja" ja "auttaakseen syöpäpotilaita". Lääketieteitä edustavat vastaajat puhuivat "hyödystä", jota he tuottavat työnsä kautta muun muassa "lääketieteen kliinisiin sovelluksiin" ja "sairauksien ehkäisyyn ja hoitoon". Vain harvat vastaajat toivat esiin yliopistotutkimuksen kautta tavoiteltavan kaupallisen hyödyn:

"Uskon myös siihen, että luonnontieteen havainnot tulevat hyödyntämään maailmaa tulevaisuudessa joka tapauksessa, vaikka välittömiä ns. hyödyntämismahdollisuuksia ei esim. kaupallistettavien keksintöjen muodossa olisi heti näköpiirissä. Minusta yliopisto on yhteiskunnassa nimenomaan se paikka, jossa kuuluisi mennä tieto ja tiede edellä." (yliopisto A, lääketiede tai biotieteet, nro 23, nainen, 40-55 vuotta) 


\section{L $\dddot{A} \ddot{K}$ E- JA BIOTIETEILIJÄT LOIVAT TYÖNSÄ}

\section{MERKITYKSELLISYYTTÄ \\ MYÖS TERVEYSPALVELUJEN \\ KEHITTÄMISEN POHJALTA.}

Vastaaja tiedostaa yliopistolle asetetut odotukset tieteen kaupallisesta hyödyntämisestä, mutta niiden sijaan hän sitoutuu tieteeseen, jonka hän asettaa vastakkain kaupallisuuden kanssa. Toinen lääke- ja biotieteitä edustava vastaaja kertoi tavoittelevansa työssään "suomalaisen yhteiskunnan toimintakykyä ja pärjäämistä globaalissa kilpailussa". Tämä kuvaus oli selkeimmin linjassa yritysmäiselle yliopistolle asetettujen hyötyodotusten kanssa.

Jotkut vastaajat asettivat yhteiskunnallisen vaikuttamisen vastakkain yritysmäisen yliopiston asettamien tuottavuusvaatimusten kanssa. Yksi lääke- tai biotiedettä edustava vastaaja kertoi panostaneensa vuosia yhteiskunnalliseen vaikuttamiseen sen sijaan, että olisi tavoitellut "vain julkaisuja ja ohjattuja väitöskirjoja”. Hän kuitenkin totesi, että "Yhteiskunnallinen vaikuttavuus on ollut erittäin aliarvostettu. Jopa siinä määrin, että olen riskeerannut uraani yliopistolla panostamalla siihen”.

\section{YLIOPISTOYHTEISÖN KEHITTÄMINEN \\ JA YHTEISTYÖN VAALIMINEN \\ HYVINVOINNIN TUOJANA}

Yliopistoyhteisöön laajasti ymmärrettynä voidaan lukea sekä yliopiston henkilöstö että opiskelijat. Erityisesti kasvatus- ja kielitieteitä edustaneet tutkija-opettajat rakensivat työnsä merkityksellisyyttä tukemalla opiskelijoita, kehittämällä yliopiston ja oman alan käytäntöjä sekä vaalimalla yhteistyötä. He sitoutuivat yhteisöllisiin tavoitteisiin, vaikka ne eivät varsinaisesti kuulu yliopistolle märiteltyihin tehtäviin. Yliopistoa pyrittiin kehittämään paremmaksi varsinkin yliopistohenkilöstön näkökulmasta, muun muassa "ruokkimaan tutkijoiden luo- vuutta ja innostusta”, edistämään "asioiden avointa käsittelyä" ja "henkilöstön osallistamista". Kasvatustieteilijät pitivät yliopisto-opetuksen tärkeänä kehittämisen kohteena, sitä haluttiin järkeistää ja kehittää opiskelijoita aktivoivaksi.

Tutkija-opettajat eri tieteenaloilta kertoivat tavoittelevansa yhteistyötä ja yhteisöllisyyttä kollegoiden kesken. He näkivät, että ne ”tekevät työstä hauskempaa, vähentävät omaa työtaakkaa ja parantavat lopputulosta" sekä "vievät kaikkien asioita eteenpäin". Kollegoita pidettiin vertaisina, joiden kanssa haluttiin jakaa "työn vastuita ja koettuja tunteita" ja "kokea solidaarisuutta". Yhteisöllisyyttä pidettiin vastakohtana yksinäisyydelle, jota muutamat vastaajat kertoivat kokeneensa yliopistossa työskennellessään. Hieman yllättäen yhteisöllisyyttä korostivat myös kilpailulliseksi mielletyn lääketieteen edustajat: Yksi totesi, että "teemme työtä yhdessä, kenenkään ei tarvitse jäädä yksin". Toinen kertoi perustaneensa oman alan tutkijoiden yhdistyksen lisäämään tutkijoiden välistä vuorovaikutusta.

Varsinkin monet kasvatus- ja kielitieteitä edustaneet vastaajat sitoutuivat auttamaan opiskelijoita heidän opinnoissaan ja edistämään heidän hyvinvointiaan. He halusivat toimia työssään opiskelijalähtöisesti ja tarjota opiskelijoille henkilökohtaista tukea. He pyrkivät olemaan helposti lähestyttäviä opettajia, joilta opiskelijat uskaltavat ongelmatilanteissa tulla kysymään. Opiskelijoiden elämäntilanteita haluttiin ottaa huomioon ja ymmärtää:

"Yritän ymmärtää opiskelijoiden tämän hetkistä tilannetta, jossa monen on opintojen ohella käytävä töissä, jotta selviää taloudellisesti. Yritän ymmärtää sitä kamppailua, jota he joutuvat käymään läsnäolopakollisten opintojen kanssa, kun kursseja menee yhtä aikaa päällekkäin. Yritän ymmärtää perheellisten opiskelijoiden arjen haasteita sekä opiskelijoiden vaikeita elämänvaiheita. Yritän kannustaa heitä etenemään opinnoissaan, mutta nähdessäni riskin uupumuksesta, koetan auttaa heitä näkemään aikalisän tarpeen" (yliopisto A, kasvatustieteet, nro 3, nainen, ikää ei ilmoitettu)

Opetuspainotteisessa tehtävässä toimineen kasvatustieteilijän sitaatti kuvaa huolta opiskelijoiden 


\section{HIEMAN YLL $\ddot{A} T$ T̈̈EN}

\section{YHTEISÖLLISYYTT ̈̈}

\section{KOROSTIVAT KILPAILULLISEKSI \\ MIELLETYN LÄÄKETIETEEN}

EDUSTAJAT.

jaksamisesta, jonka useat tutkija-opettajat toivat esiin ja jonka vuoksi he kokivat opiskelijoiden tukemisen ja kannustamisen tärkeäksi.

\section{YLIOPISTOTYÖ MERKITYKSELLISYYDEN LÄHTEENÄ JA KYYNISYYDEN TYYSSIJANA}

Sen lisäksi, että tutkija-opettajat rakensivat työnsä merkityksellisyyttä työskentelemällä tiedettä, opiskelijoita, yhteiskuntaa ja työyhteisöä varten, he kertoivat saavansa työstään paljon itselleen. Tätä näkökulmaa voi Rosewellin ja Ashwinin $(2019,5)$ tavoin luonnehtia itseen keskittyväksi (self-focused), jolla viitataan henkilökohtaisten intressien nousemiseen keskeiseen asemaan työn merkitystä pohdittaessa. Tutkija-opettajien kirjoittamista kuvauksista tuli vahvasti esiin yliopistotyölle annettujen henkilökohtaisten merkitysten moninaisuus tieteenalojenkin sisällä. Työtä luonnehdittiin yhtäältä "intohimona", "harrastuksena", "elämäntapana", jopa "olemassaolon oikeutuksen perustana" ja "kutsumuksena". Toisaalta se nähtiin "leivän pöytään" tuojana ja "jokapäiväisenä puurtamisena”.

Tutkija-opettajat rakensivat oman työn merkitystä koko elämän kontekstissa. Yhteensä 52 vastaajaa, eli noin 44 prosenttia kaikista vastaajista, kertoi työn merkitsevän heille paljon tai olevan tärkeä osa omaa elämää tai identiteettiä, minkä voi tulkita vahvaksi identifioitumiseksi omaan työhön. He kertoivat työn merkitsevän heille "lähes kaikkea" ja kuvasivat sitä "ainoana tekemisenä, jossa on jotain järkeä", "merkittävänä osana minäkuvaani” ja niin mielekkäänä, että sitä voisi tehdä palkattakin.

Työn nähtiin antavan "loputtomasti haasteita", sitä pidettiin palkitsevana ja onnistumisen kokemuksia tuovana asiana, mahdollisuutena "löytää jotain uutta ja potentiaalisesti tärkeää" ja "saada joskus aikaan jotain suurta". Työn merkityksellisyys korostui erityisesti yliopisto A:n läk̈ke- ja biotieteellistä tiedekuntaa edustavissa vastaajissa, joista jopa 63 prosenttia kuvasi työtään tärkeänä osana itseä tai omaa elämää. Heistä puolet työskenteli tutkimuspainotteisissa tehtävissä.

Tutkija-opettajat eri tieteenaloilla kertoivat yliopistotyön merkitsevän heille itsenäisyyttä ja vapautta päättää itse oman työnsä sisällöstä ja siitä, miten työtä tekee. Työtä pidettiin tapana vaikuttaa itselle henkilökohtaisesti tärkeisiin asioihin ja pyrkiä oman arvopohjan mukaisesti kohti itselle merkityksellisiä päämääriä:

"Haluan tehdä työtä joka on minulle henkilökohtaisesti mielekästä. Siksi omaehtoinen tutkimus, jossa itse määritän tutkittavan kohteen, on minulle tärkeää" (yliopisto A, kielitieteet, nro 2, nainen, 40-55 vuotta)

Sitaatissa ilmenee autonomian ja työn mielekkyyden välinen suhde. Mahdollisuutta työskennellä itse määriteltyjen arvojen ja tavoitteiden mukaisesti pidettiin työn merkityksellisyyden kokemusta lisäävänä asiana (ks. myös Tapanila, Siivonen \& Filander 2020).

Monet tutkija-opettajat eri tieteenaloilta kertoivat haluavansa oppia ja kehittyä työnsä ohessa. He näkivät akateemisen työn elinikäisenä oppimisensa ja sivistävänä asiana, mahdollisuutena syvemmän ymmärryksen saavuttamiseen sekä itsensä haastamiseen ja kehittämiseen. Oman ymmärryksen lisääntyminen nähtiin tärkeänä paitsi itsen myös opiskelijoiden kannalta. Yksi kasvatustieteitä edustanut tutkija-opettaja totesi, "että oppisi itse ymmärtämään ja ehkä myös voisi välittää sitä muille." Itseen keskittyvät intressit osittain kietoutuivat hyvän tuottamiseen muille ihmisille.

Jotkut tutkija-opettajat toivat esiin halunsa tehdä työnsä hyvin ja laadukkaasti sekä olla hyvä työssään. Näin he pyrkivät paitsi tyydyttämään omaa kunnianhimoa myös saamaan arvostusta muilta. Arvostuksen kaipuu tuli esiin myös Rosewellin ja Ashwinin (2019, 5-6) tutkimuksessa, jossa tarve ammatilliseen tunnustukseen, tunnettuuteen ja asiantuntijaaseman saamiseen nousi tärkeäksi tutkijan roolia 


\section{HEIKENTYNEESEEN TYÖN}

MERKITYKSELLISYYDEN

KOKEMUKSEEN LIITTYI USEIN

KYYNISTYMINEN.

määrittäväksi tekijäksi. Omassa aineistossani erityisesti osa kasvatus- ja kielitietelijöistä kuitenkin kertoi kokeneensa oman työnsä, asemansa tai tieteenalansa arvostuksen vähentyneen yritysmäiselle yliopistolle ominaisen tuottavuuseetoksen vahvistumisen myötä. Moni näistä vastaajista yhdisti arvostuksen puutteen omaan kokemukseensa työn merkityksellisyyden vähenemisestä. Esimerkiksi yksi kielitieteitä edustava vastaaja totesi, että " on vaikeaa perustella itselleen miksi tekee tätä työtä, jota yliopistohallinto ei pidä tarpeellisena ja jota mitataan vain 'maisteritutkintojen’ määrällä”.

Erityisesti osa läke- ja biotieteitä edustavista vastaajista kertoi tavoittelevansa työssään menestystä akateemisella uralla tai väitöskirjan tai muun tutkimusprojektin loppuun saattamista. Akateemisella urapolulla etenemistä pidettiin velvoittavanakin asiana, jos halusi pysyä yliopistomaailmassa. Kaikki vastaajat eivät kuitenkaan pohtineet työssään tavoittelemiaan asioita henkilökohtaisten intressien pohjalta, vaan tavoitteita saattoivat ohjata myös yliopistolta yleisesti odotettavat asiat:

"[--] tutkimusrahoituksen hankkiminen ja tulosten eteenpäin vieminen. Nämä seikat ovat ensisijaisia tavoitteita kaikille muillekin yliopistossa työskenteleville tutkijoille." (yliopisto B, lääketiede tai biotieteet, nro 48, mies, 40-55 vuotta)

Tämä sitaatti poikkesi muista siten, että se ilmensi yritysmäisen yliopiston odotusten ja tavoitteiden hallitsevaa asemaa suhteessa tutkija-opettajien itse työlleen antamiin merkityksiin. Vastaaja näytti omaksuneen yritysmäisen yliopiston odotukset omiksi tavoitteiseen, ja kysyttäessä työn merkitystä hänelle itselleen hän toi esiin ainoastaan työn merkityksen toimeentulona.
Jotkut tutkija-opettajat totesivat, että työ merkitsee heille liiankin paljon. He korostivat perheen ja yksityiselämän merkitystä rajatakseen työn elämästä ottamaa tilaa. Toiset vastaajat kertoivat työn henkilökohtaisen merkityksellisyyden ja työtä kohtaan koetun intohimon vähentyneen muun muassa siksi, että muutokset yliopistossa eivät mahdollistaneet työn tekemistä parhaalla mahdollisella tavalla. Muun muassa yliopisto B:ssä työskentelevät lääketieteilijät toivat esiin resurssien vähyyttä, kiirettä, riittämättömyyden tunnetta ja rahan valtaa, joiden he näkivät vähentävän työn merkityksellisyyden kokemusta. He myös korostivat vähemmän työn merkityksellisyyttä kuin yliopisto A:ssa työskentelevät lääke- ja biotieteilijät.

Heikentyneeseen työn merkityksellisyyden kokemukseen näytti usein liittyvän kyynistyminen, jota yksi kielitieteitä edustava tutkija-opettaja kuvasi seuraavasti: "Miksi suunnitella jotain uutta ja jännittävää, kun suoritteita lasketaan tietyllä kaavalla, eikä sisällöillä ole oikeasti merkitystä sille porukalle, joka tekemisiä arvioi." Kyynistymistä toivat esiin myös kasvatustieteitä ja lääke- ja biotieteitä edustavat vastaajat. Jos vastaaja ei nostanut esiin oman työnsä merkityksellisyyttä tai totesi sen vähentyneen, hän tyypillisesti korosti työstä saamiaan konkreettisia hyötyjä, kuten palkkaa, pysyvää työsuhdetta tai yliopistouralla etenemistä. Näiden asioiden voi tulkita kompensoivan hänen kokemaansa työn merkityksellisyyden puutetta.

\section{POHDINTA}

Olen tarkastellut eri tieteenaloja edustavien tutkija-opettajien tapoja rakentaa työnsä merkityksellisyyttä suhteessa yliopistotyölle asetettuihin vaatimuksiin ja niiden muutokseen. Aineistossani tutkija-opettajat rakentavat työnsä merkityksellisyyttä puheen kautta aineksista, joita on tarjolla heidän narratiivisessa ympäristössään (Gubrium \& Holstein 2008). Prosessia ohjaa moraalinen kehys, jonka ulottuvuuksia ovat merkityksellisyyden kokemisen lisäksi velvollisuudet muita kohtaan ja muilta saatava arvostus itseä kohtaan (Henkel 2005; Taylor 1989). 


\section{VARSINKIN TYÖLLE}

\section{ANNETTAVAT MERKITYKSET}

\section{OLIVAT USEIN VAHVASTI}

YKSILÖLLISI $\ddot{A}$.

Erityisesti kasvatus- ja kielitieteilijät näkivät heille ominaisen sivistyseetoksen ristiriitaisena yritysmäisen yliopiston odottamien määrällisten tulosten tavoittelun kanssa. He kokivat edustamansa tieteenalan ja siten myös oman työnsä arvostuksen vähentyneen mitattavia tuloksia korostavassa yliopistossa, mikä on vaikuttanut kielteisesti työn merkityksellisyyden kokemiseen. Seurauksena arvostuksen puutteesta he identifioituivat moraalisen kehyksensä ohjaamina yhteiskunnalliseen vaikuttamiseen sen sijaan, että olisivat vastanneet yliopiston odotuksiin tuottamalla suoritteita. Arvostusta lisätäkseen jotkut kasvatus- ja kielitieteilijät korostivat puheessaan oman työnsä ja tieteenalansa tärkeyttä sekä yliopistolle että yhteiskunnalle.

Lääke- ja biotieteilijät identifioituivat abstraktien sivistysyliopiston ihanteiden sijaan sairauksien hoitamiseen ja ammatillisten taitojen opettamiseen opiskelijoille. Konkreettiset, mitattavissa olevat tuotokset sopivat hyvin yhteen yritysmäisen yliopiston odotusten kanssa ja saavat todennäköisesti arvostusta myös yhteiskunnalta, joka odottaa yliopistolta selkeästi osoitettuja hyötyjä. Näin lääke- ja biotieteilijät eivät kokeneet yliopiston yritysmäistymisen uhanneen tieteenalansa arvostusta ja asemaa. Yritysmäiseen yliopistoon identifioitumiseen viittasi "huippupuhe", jota jotkut lääke- ja biotieteiden edustajat käyttivät työnsä tavoitteita pohtiessaan. Lääke- ja biotieteiden edustajien moraalisen kehyksen voi siis tulkita olleen vähiten ristiriidassa yritysmäisen yliopiston tavoitteiden kanssa.

Lääketieteen edustajien suhtautuminen yritysmäiseen yliopistoon ei kuitenkaan ollut aineistossani yhtenäistä. Yliopisto B:ssä työskentelevät lääketieteilijät korostivat vähemmän työn merkityksellisyyttä kuin yliopisto A:ssa työskentelevät ja näkivät sen vähentyneen tehokkuuspaineiden ja taloudellisten arvojen vahvistumisen myötä. Vaikka lääketieteilijät ovat kokeneet yliopistouudistukset muita tieteenaloja myönteisempinä (ks. Rinne ym. 2012), hekään eivät siis ole täysin välttyneet yliopiston yritysmäistymisen varjopuolilta.

Samaa tieteenalaa edustaneet tutkija-opettajat käyttivät osittain samanlaisia puhetapoja omaa työtään pohtiessaan, mutta tieteenala ei yksiselitteisesti määrittänyt aineksia, joista he rakensivat työnsä merkityksellisyyttä. Varsinkin työlle annettavat merkitykset olivat usein vahvasti yksilöllisiä; esimerkiksi kielitieteilijä saattoi nähdä työnsä sivistyksellisen kasvatustehtävän sijaan asiakaspalveluna, vaikka tällainen puhetapa oli tieteenalalle epätyypillinen. Puhetapojen ja työlle annettujen merkitysten eroja tieteenalojen sisällä todennäköisesti selittävät tutkija-opettajien erilaiset työtehtävät ja asemat, joiden vaikutusta tässä tutkimusasetelmassa pystyi tarkastelemaan vain rajallisesti.

Tieteenaloja yhdisti se, että yritysmäiselle yliopistolle ominaisten tuottavuus- ja tehokkuustavoitteiden katsottiin uhkaavan yliopistossa tehtävän tutkimuksen tieteellistä laatua, joka oli tutkijaopettajille tärkeä työn merkityksellisyyden lähde. Yhtenä reaktiona yritysmäisen yliopiston asettamiin paineisiin voi pitää tutkija-opettajien halua auttaa ja tukea opiskelijoita, joiden jaksaminen on koetuksella ainakin osittain heihinkin kohdistuvien tehokkuuspaineiden takia. Samoin tarve edistää yhteisöllisyyttä voi olla vastareaktiota yksilökeskeisen kilpailullisuuden korostumiseen yliopistossa (ks. myös Hannukainen \& Brunila 2017, 105). Opiskelijoiden tukemista ja yhteisöllisyyden vaalimista voidaankin pitää uusina aineksina työn merkityksellisyyden rakentamiseen.

Tutkija-opettajat eivät työnsä tavoitteista puhuessaan juurikaan identifioituneet yritysmäisen yliopiston odotuksiin suurten julkaisu- ja opetusmäärien tuottamisesta ja ulkopuolisen rahoituksen hankkimisesta. He kuitenkin toivat esiin, että yliopisto odotti heiltä oman uran edistämistä tuottamalla julkaisuja ja hakemalla rahoitusta. Lisääntynyt kyynistyminen näytti samoin muokkaavan yliopistotyölle annettuja merkityksiä välineelliseen suuntaan; jos työtä 
ei enää koeta itselle merkitykselliseksi, sen merkitys saattaa pelkistyä palkan ansaitsemiseksi (ks. myös Clark 1997).

Työn merkityksen rajaaminen oman elämän kontekstissa voi kertoa siitä, että talouden arvoihin ja mitattaviin suoritteisiin keskittyvässä yritysmäisessä yliopistossa ei välttämättä ole tilaa Ylijoen (2009) kuvaamaan lumotarinaan kuuluvalle vahvalle sitoutumiselle omaan työhön. Tutkija-opettajat saattavat nähdä yliopiston yritysmäistymisen myötä kasvaneet suorituspaineet ja vahvan työhön sitoutumisen liian kuormittavana yhdistelmänä.

Yliopistolta odotetaan yhteiskunnallista vaikuttavuutta, joka tutkimukseni perusteella myös näyttää lisäävän työn merkityksellisyyden kokemusta. Yhteiskunnallista vaikuttavuutta on kuitenkin vaikea mitata yliopiston käyttämin määrällisin indikaattorein, eivätkä siihen panostavat tutkija-opettajat siten välttämättä saa tunnustusta ja arvostusta yliopistossa. Jos yliopisto kannustaa työntekijöitään sitoutumaan pääosin omaa uraa edistävään toimintaan, se ei välttämättä kykene tuottamaan yliopistolta odotettavaa yhteiskunnallista hyötyä ja vaikuttavuutta. Lisäksi tutkija-opettajien vähentynyt työhön sitoutuminen voi heikentää heidän työnsä laatua. Seurauksena yliopistouudistuksen tavoitteet tutkimuksen ja opetuksen laadun ja vaikuttavuuden parantamiseksi saattavat lopulta jäädä saavuttamatta.

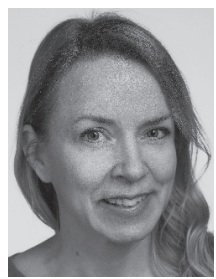

\section{KATRIINA TAPANILA}

KM, KTM, projektitutkija

kasvatustieteiden ja kulttuurin

tiedekunta

Tampereen yliopisto

(D) https://orcid.org/0000-00021361-5413

\section{LÄHTEET}

Apo, S. (1995). Naisen väki: tutkimuksia suomalaisten kansanomaisesta kulttuurista ja ajattelusta. Helsinki: Hanki ja jää.

Ash, M. G. (2008). From 'Humboldt' to Bologna: History as discourse in higher education in reform debates in German-speaking Europe. Teoksessa B. Jessop, N. Fairclough \& T. Wodak (toim.) Education and the Knowledge-based Economy in Europe. Rotterdam: Sense Publishers, 41-62.

Becher, T. (1989). Academic tribes and territories. Milton Keynes: Open University Press.

Becher, T. (1994). The Significance of Disciplinary Differences. Studies in Higher Education 19(2), 151-61.

Björn, I., Saarti, J. \& Pöllänen, P. (2017). Yliopistot talousvetureiksi. Suomalaiset yliopistot ja yliopistojen tuottama sivistys tehostamistalouden kohteena. Teoksessa T. Eskelinen, H. Harjunen, H. Hirvonen \& E. Jokinen (toim.) Tehostamistalous. Jyväskylä: SoPhi, 140-162.

Clark, B.R. (1997). Small worlds, different worlds: The uniqueness and troubles of American academic profession. Daedalus, 126, 21-41.

Clegg, S. (2008). Academic Identities Under Threat? British Educational Research Journal 34(3), 329-45.
Cohen-Meitar, R., Carmeli, A. \& Waldman, D. A. (2009). Linking meaningfulness in the workplace to employee creativity: The intervening role of organizational identification and positive psychological experiences. Creativity Research Journal 21(4), 361-375.

Eskola, J. \& Suoranta, J. (2014). Johdatus laadulliseen tutkimukseen. Tampere: Vastapaino.

Gubrium, J. \& Holstein, J. (2008). "Narrative Ethnography." Teoksessa N. Hesse-Biber, \& P. Leavy, P. (toim.). Handbook of Emergent Methods. New York: The Gilford Press, 241-64.

Hakala, J. (2009). The future of the academic calling? Junior researchers in the entrepreneurial university. Higher Education 57(2), 173-190.

Hannukainen, K. \& Brunila, K. (2017). "Jokainen verissä päin sitä omaa edistää". Tutkijakoulutus, tieto ja tutkijuus tietokapitalismissa. Aikuiskasvatus 37(2), 96-107.

Heikkinen, H. L. T. (2001). Narratiivinen tutkimus todellisuus kertomuksena. Teoksessa Aaltola, J. \& Valli, R. (toim.). Ikkunoita tutkimusmetodeihin. Jyväskylä: PS-kustannus. 116-132.

Henkel, M. (2005). Academic identity and autonomy in a changing policy environment. Higher Education 49(1), 155-176. 
Himanka, J. (2018). Korkein opetus. Opettaminen yliopistoissa ja korkeakouluissa: Johdatus opettajalle. Tampere: Vastapaino.

Hänninen, V. (1999). Sisäinen tarina, elämä ja muutos. Tampere: Tampereen yliopisto.

Kallio, K.-M., Kallio, T., Tienari, J. \& Hyvönen T. (2016). Ethos at stake: Performance management and academic work in universities. Human Relations 69(3), 685-709.

Kankaanpää, J. (2013). Kohti yritysmäistä hyötyyliopistoa. Valtiovallan tahto Suomessa vuosina 1985-2006 ja kokemukset kolmessa yliopistossa. Turun yliopiston julkaisuja. Sarja C. osa 369. Turku: Turun yliopisto.

Kolbe, L. (1996). Jäähyväiset valtiolle? Teoksessa B. Helenius, B., Hämäläinen, E. \& J. Tuunainen (toim.) Kohti McDonald's-yliopistoa. Näkökulmia suomalaiseen korkeakoulu- ja tiedepolitiikkaan. Helsinki: Tammi, 13-34.

Komulainen, K.; Hirvonen, I.; Kaskes, K., Kasanen, K. \& Siivonen, P. (2019). Asiantuntijoita, monitaitoisia ja akateemisia yrittäjiä. Yliopisto-opiskelijoiden asemoituminen akateemisuuteen, työllistettävyyteen ja yrittäjyyteen. Aikuiskasvatus 39(2), 112-137.

Koski, L. (2002). Yliopiston sisäinen toimintalogiikka 1900-luvun lopun muutoksissa. Teoksessa S. Ahola \& J. Välimaa (toim.) Heimoja, hengenviljelyä ja hallintoa. Korkeakoulututkimuksen vuosikirja 2002. Jyväskylä: Jyväskylän yliopisto, 33-51.

Laajalahti, A. (2015). Tutkijoiden attribuutiot. Mistä vuorovaikutusosaaminen tai sen puute johtuu? Aikuiskasvatus 35(1), 16-27.

May, D. R., Gilson R. L. \& Harter L. M. (2004). The Psychological Conditions of Meaningfulness, Safety and Availability and the Engagement of the Human Spirit at Work. Journal of Occupational and Organizational Psychology 77, 11-37.

Miettinen, R., Tuunainen J., Knuuttila, T. \& Mattila, E. (2006). Tieteestä tuotteeksi. Yliopistotutkimus muutosten ristipaineessa. Helsinki: Yliopistopaino.

Miettinen, R. (2018). Humboldt vai Snellman? Minkälainen sivistysyliopisto. Tieteessä tapahtuu 36(1), 3-14.

Opetus- ja kulttuuriministeriö (2017). Yliopistolaitoksen uudistaminen. http://80.248.162.139/OPM/Koulutus/ koulutuspolitiikka/Hankkeet/Yliopistolaitoksen_ uudistaminen/?lang=fi (25.4.2017).

Pasanen, H. (2015). Kyky koulutuksen taloudessa. Teoksessa K. Brunila, J. Onnismaa \& H. Pasanen (toim.) Koko elämä töihin. Koulutus tietokykykapitalismissa. Tampere: Vastapaino, 58-80.
Pratt, M. G. \& Ashforth, B. E. (2003). Fostering Meaningfulness in Working and at Work. Teoksessa K. S. Cameron, J. E. Dutton \& R. E. Quinn (toim.) Positive Organizational Scholarship. San Francisco: Berret-Koehler Publishers, 309-327.

Raatikainen, P. \& Tunkkari, H. (1991). Nopeammin, tehokkaammin, tuloksellisemmin tiedepolitiikka 1990-luvulla? Helsinki: Gaudeamus.

Rinne, R., Jauhiainen, A., Simola, H., Lehto, R., Jauhiainen, A. \& Laiho, A. (2012). Valta, uusi yliopistopolitiikka ja yliopistotyö Suomessa. Managerialistinen hallintapolitiikka yliopistolaisten kokemana. Suomen kasvatustieteellisen seuran Kasvatusalan tutkimuksia -sarja.

Rosewell, K., \& Ashwin P. (2019). Academics' perceptions of what it means to be an academic, Studies in Higher Education 44(12), 2 374-2 384.

Tapanila, K., Siivonen, P. \& Filander, K. (2020). Academics' social positioning towards the restructured management system in Finnish universities, Studies in Higher Education 45(1), 117-128.

Taylor, C. (1989). Sources of the Self: The Making of the Modern Identity. Cambridge: Cambridge University Press.

Tirronen, J. (2005). Modernin yliopistokoulutuksen lähtökohdat ja sivistyskäsitys. Kuopion yliopiston julkaisuja E. Yhteiskuntatieteet 122. Kuopion yliopisto.

Tomperi, T. (2009). Yliopistolaki taustoineen. Koulutuspoliittinen tarkastelu. Teoksessa Tomperi, T. (toim.) Akateeminen kysymys? Yliopistolain kritiikki ja kiista uudesta yliopistolaista. Tampere: Vastapaino, 147-202.

Williams, P. J. (2007). Valid knowledge: the economy and the academy. Higher Education 54(4), 511-523.

Ylijoki O.-H. (1998) Akateemiset heimokulttuurit ja noviisien sosialisaatio. Tampere: Vastapaino.

Ylijoki, O.-H. (2009). Yliopiston lumo. Teoksessa Tomperi, T. (toim.) Akateeminen kysymys? Yliopistolain kritiikki ja kiista uudesta yliopistolaista. Tampere: Vastapaino, 83-92.

Ylijoki, O.-H. \& Ursin, J. (2013). The construction of academic identity in the changes of Finnish higher education. Studies in Higher Education 38(8), 1 135-1 149 